\title{
Improvement of law enforcement officers training to act in emergency situations
}

\author{
P.N. Voynov ${ }^{*}$, S.I. Kramskoy ${ }^{2}$, and I.A. Amelchenko ${ }^{3}$ \\ ${ }^{1}$ I.D. Putilin Belgorod Law Institute of the Ministry of Internal Affairs of Russia, Belgorod, Russia \\ ${ }^{2}$ V.G. Shukhov Belgorod State Technological University, Belgorod, Russia \\ ${ }^{3}$ V.G. Shukhov Belgorod State Technological University, Belgorod, Russia
}

\begin{abstract}
The article presents a method of stage-by-stage training of law enforcement officers and proves its efficiency. The analysis of law enforcement officials' professional qualifications shows the lack of knowledge about action plans in special conditions. The presented situation leads to the employee's injuries or death, as well as failure of the operation being conducted. As a consequence, the Internal Affairs Agencies need highly qualified specialists who are able to perform operational service tasks in emergency situations. Similarly, the decline in the level of professional training is due to the change of generations and retirement of highly qualified law enforcement officers. There is a trend that characterizes the decrease in the efficiency of work related to the improvement of the personnel's qualifications. The presented method defines the time duration of the stages, tasks and goals for each stage, conditions created at each stage and a form of control.
\end{abstract}

\section{A problem statement}

Considering criminalization of public relations and rise in crime in recent years the police officers' activities are carried out in conditions and circumstances that create an unusual and unsafe environment. Therefore, it is urgent to improve the training system to prepare them for effective performance of operational service tasks in emergencies.

The purpose of this study is to identify the ways how to improve the system of law enforcement officers' training to act in emergencies on the basis of step-by-step preparations. The stages of training were determined taking into account the police officers' adaptation to the extreme conditions of operational service activities.

\subsection{The objective of the work}

The experiment involved 285 fourth-year cadets (98 girls and 187 boys) of Belgorod Law Institute of the Ministry of Internal Affairs of Russia named after I.D. Putilin and it was conducted in the framework of discipline "Tactical and special training".

* Corresponding author: ipcs-profped@yandex.ru 
The stages of the students' adaptation to extreme conditions were taken into account when forming skills in this discipline. To assess the cadets' psychological and motivational characteristics a questionnaire was conducted; it included the following tests and surveys: SACS test [1], the express-method of studying psychosocial climate in the work collective [2], the visual-analog scale method for assessing the anxiety [3] and the "Career Anchors" method [4]. The survey was carried out at the beginning and end of the experiment. Mathematical statistics were used to evaluate the results.

\section{Materials and the results of the research}

Tactical and special training is one of the main elements of integrated system of law enforcement officers' training to act in special conditions. In this regard the process of improving the tactical and special training of police officers should not be spontaneous. It is supposed to be purposeful, pedagogically justified and organized in various forms, as it is indicated by S. Katz and D. Kalk [5, 6].

In their works S.N. Barkalov and I.V. Gerasimov [7] consider the analysis of the professional training system organization, which revealed a number of contradictions:

- evaluation criteria for employees' proficiency differ in local Agencies of Internal Affairs and educational organizations;

- large amounts of information are limited by the number of training hours;

- the content of the training do not correspond to the specifics of practical activities;

- the training methods used are not effective enough.

Y.L. Pomerantsev and V.I. Stepanyuk [8,9] distinguish the main causes of reduced efficiency of police officers' tactical and special training: vagueness of goals setting in education; difficult quantitative assessment of the moment of their achievement; there is no scientifically valid approach in defining the training content; the use of mainly passive methods of training.

The studies presented by N.A. Alekseev, N.B. Kutergin, P.N. Voynov, A.N. Vorotnik [10], V.A. Zolotenko [11] cover only general issues related to the activity of law enforcement officers in special conditions.

V.A. Tarasov and L.I. Timoshenko [12] highlight the common problems of law enforcement officers' complex training for service and fighting activities. The current practice of law enforcement officers' training is interpreted as the following: the goals of training are initially defined as acquisition of general knowledge in a separate discipline, which results in separation of knowledge from practical activities. Students use this knowledge only for passing tests and exams. As a result, there is an inability to apply the acquired knowledge even in the simplest practical situation.

The most important principles that express the organizational structure of police officers' tactical and special training are: continuity; regularity; alternation of load and rest; consistency; distribution of training material; cyclicality; dynamism and constancy (stages); specialization; multi-directional rhythm; feedback (J. Niehaus) [13].

A.A. Trebenok [14] considers simulating tactical and special training as managing a complex process consisting of: training goals setting; defining the quality indicator of tactical task understanding; structural synthesis of the model of tactical and special training processes; selection of constituent elements and identification of relationships between them; descriptions of the constituent elements of the simulation.

The analysis of professional qualifications of the personnel of the Ministry of Internal Affairs indicates the lack of basic knowledge about the algorithms of actions in special conditions. This situation leads to the employee's injuries or death, disruption of the operation, respectively, the Agencies of Internal Affairs need highly qualified specialists who are able to perform operational service tasks effectively in emergencies [15]. 
Many authors agree that in extreme conditions law enforcement officers' successful actions require high tactical, physical and emotional-volitional level of training $[16,17,18$, $19,20]$. The distinctive feature of such training is taking into account the individual characteristics of the employees and patterns that contribute to the emergence and functioning of the mental process that characterizes a specific activity [21, 22, 23].

Thus, while analyzing domestic and foreign literature we revealed an insufficient level of elaboration of law enforcement officers' training system to act in emergency situations. Further study is required to identify the ways of improving the police officers' training to act in such conditions.

The structure of the experimental technique is shown in the table (table 1). During the experimental period there were significant changes in the indicators that characterize motivational and value-based attitudes in the collective environment (table 2). Despite the fact that the requirements and standards became more complicated at each subsequent stage of training, in the experimental group the academic progress in practical component improved by $0.36-0.42$ points.

Table 1. Stages and conditions created at each stage.

\begin{tabular}{|c|c|c|c|}
\hline Stage & Tasks & $\begin{array}{l}\text { Conditions created at } \\
\text { this stage }\end{array}$ & Form of control \\
\hline $\begin{array}{l}\text { I } \\
\text { stage }\end{array}$ & $\begin{array}{l}\text { Development of physical } \\
\text { qualities. } \\
\text { Formation of skills for } \\
\text { overcoming fear. } \\
\text { Formation of the ability to } \\
\text { navigate in space. } \\
\text { Formation of the ability to } \\
\text { perform tasks being } \\
\text { exhausted. } \\
\text { Formation and } \\
\text { improvement of the } \\
\text { ability to overcome } \\
\text { various obstacles. }\end{array}$ & $\begin{array}{l}>\text { Training sessions in } \\
\text { complicated conditions: } \\
\text { and mental stress; } \\
>\text { intensity of light } \\
\text { and sound irritation } \\
\text { typical for emergency } \\
\text { situations; } \\
>\text { lack of necessary } \\
\text { information and time; } \\
>\text { difficult weather } \\
\text { conditions; long period of } \\
>\text { long } \\
\text { intense activity while } \\
\text { using personal protective } \\
\text { equipment; need to } \\
\text { constant natural and } \\
\text { overcome natural artifial obstacles. } \\
\text { artificial }\end{array}$ & $\begin{array}{l}\text { Development of physical and } \\
\text { psychological qualities and } \\
\text { improvement of the level of } \\
\text { skills to be prepared to act in } \\
\text { these conditions. } \\
\text { Taking a credit in practical } \\
\text { aspects of the above sections. } \\
\text { Development and handing out } \\
\text { of recommendations to } \\
\text { eliminate shortcomings in the } \\
\text { tactics of actions in the above } \\
\text { conditions. }\end{array}$ \\
\hline $\begin{array}{l}\text { II - } \\
\text { stage }\end{array}$ & $\begin{array}{l}\text { Development of physical } \\
\text { qualities. } \\
\text { Improvement of the } \\
\text { ability to navigate in } \\
\text { space. } \\
\text { Development of the } \\
\text { ability to perform tasks } \\
\text { being ex-hausted. } \\
\text { Improvement of the } \\
\text { ability to overcome } \\
\text { various obstacles. }\end{array}$ & $\begin{array}{l}>\text { Complication of the } \\
\text { situation with the } \\
\text { principle of surprise: } \\
\text { simulation tools at short } \\
\text { distance; } \\
\text { malfunction; weapon } \\
\text { introductory change of the } \\
\text { surrounding environment, } \\
\text { which requires immediate } \\
\text { and active actions; } \\
\text { hidden preparations and } \\
\text { unexpected use of various } \\
\text { obstacles during } \\
\text { personnel's performing of }\end{array}$ & $\begin{array}{l}\text { Development of physical and } \\
\text { psychological qualities and } \\
\text { improvement of the level of } \\
\text { skills to be prepared to act in } \\
\text { these conditions. } \\
\text { Taking a credit in practical } \\
\text { aspects of the above sections. } \\
\text { Development and handing out } \\
\text { of recommendations to elimi- } \\
\text { nate shortcomings in the tac- } \\
\text { tics of actions in the above } \\
\text { conditions. }\end{array}$ \\
\hline
\end{tabular}




\begin{tabular}{|c|c|c|c|}
\hline Stage & Tasks & $\begin{array}{l}\text { Conditions created at } \\
\text { this stage }\end{array}$ & Form of control \\
\hline & & $\begin{array}{l}\text { tactical and technical } \\
\text { actions; } \\
\text { unexpected training alert; } \\
\text { training sessions in an } \\
\text { unfamiliar area. }\end{array}$ & \\
\hline $\begin{array}{l}\text { III - } \\
\text { stage }\end{array}$ & $\begin{array}{l}\text { Development of physical } \\
\text { qualities. } \\
\text { Improvement of the } \\
\text { ability to navigate in } \\
\text { space in different } \\
\text { conditions (limited time, } \\
\text { lighting and so on). } \\
\text { Development of the } \\
\text { ability to perform tasks in } \\
\text { different conditions. }\end{array}$ & $\begin{array}{l}\text { The principle of "security } \\
\text { threat". } \\
\text { conditions were created } \\
\text { with the use of organized } \\
\text { procedures that contribute } \\
\text { to the emergence of a real } \\
\text { threat and shortage of } \\
\text { time, which cause long- } \\
\text { term emotional stress; } \\
\text { various obstacles that } \\
\text { make the officers feel } \\
\text { increased responsibility } \\
\text { for their own actions, } \\
\text { which ensures the } \\
\text { successful performance of } \\
\text { the service and combat } \\
\text { task. }\end{array}$ & $\begin{array}{l}\text { Development of physical and } \\
\text { psychological qualities and } \\
\text { improvement of the level of } \\
\text { skills to be prepared to act in } \\
\text { these conditions. } \\
\text { Taking a credit in practical } \\
\text { aspects of the above sections. } \\
\text { Development and handing out } \\
\text { of recommendations to } \\
\text { eliminate shortcomings in the } \\
\text { tactics of actions in the above } \\
\text { conditions. }\end{array}$ \\
\hline
\end{tabular}

The control group demonstrated poorer academic performance, but at the same time $31 \%$ of the employees improved their level of training at the stage of final control.

Table 2. Comparative analysis of changes in motivational and value-based attitudes of cadets.

\begin{tabular}{|c|c|c|c|c|c|c|c|c|c|c|c|c|c|}
\hline \multirow{2}{*}{\multicolumn{2}{|c|}{$\begin{array}{l}\text { Stage of } \\
\text { experiment }\end{array}$}} & \multicolumn{4}{|c|}{ Test SACS } & \multicolumn{4}{|c|}{$\begin{array}{l}\text { Express-method of } \\
\text { studying } \\
\text { psychosocial } \\
\text { climate in the } \\
\text { work collective }\end{array}$} & \multicolumn{4}{|c|}{$\begin{array}{l}\text { Visual-analog scale } \\
\text { method for assessing } \\
\text { anxiety }\end{array}$} \\
\hline & & M & \pm & $\mathbf{m}$ & $\mathbf{P}$ & M & \pm & m & $\mathbf{P}$ & $\mathbf{M}$ & \pm & m & $\mathbf{P}$ \\
\hline \multirow{2}{*}{$\mathrm{CG}$} & $\begin{array}{l}\text { Before } \\
\text { experiment }\end{array}$ & $\begin{array}{l}0,9 \\
1\end{array}$ & \pm & $\begin{array}{l}0,1 \\
7\end{array}$ & & $\begin{array}{l}0,1 \\
2\end{array}$ & \pm & $\begin{array}{l}0,1 \\
3\end{array}$ & & $\begin{array}{l}72,3 \\
3\end{array}$ & \pm & $\begin{array}{l}12,7 \\
8\end{array}$ & \\
\hline & $\begin{array}{l}\text { After } \\
\text { experiment }\end{array}$ & $\begin{array}{l}0,9 \\
5 \\
\end{array}$ & \pm & $\begin{array}{l}0,1 \\
8 \\
\end{array}$ & & $\begin{array}{l}0,1 \\
5 \\
\end{array}$ & \pm & $\begin{array}{l}0,0 \\
9 \\
\end{array}$ & & $\begin{array}{l}58,3 \\
1 \\
\end{array}$ & \pm & $\begin{array}{l}16,5 \\
4 \\
\end{array}$ & \\
\hline \multirow{2}{*}{ EG } & $\begin{array}{ll}\begin{array}{l}\text { Before } \\
\text { experiment }\end{array} & \text { the } \\
\end{array}$ & $\begin{array}{l}0,8 \\
2\end{array}$ & \pm & $\begin{array}{l}0,1 \\
2\end{array}$ & \multirow{2}{*}{$\begin{array}{l}* \\
* \\
*\end{array}$} & $\begin{array}{l}0,0 \\
8 \\
\end{array}$ & \pm & $\begin{array}{l}0,1 \\
2\end{array}$ & \multirow{2}{*}{$*$} & $\begin{array}{l}67,0 \\
9 \\
\end{array}$ & \pm & $\begin{array}{l}18,1 \\
9\end{array}$ & \multirow{2}{*}{$\begin{array}{l}* \\
* \\
*\end{array}$} \\
\hline & $\begin{array}{l}\text { After } \\
\text { experiment }\end{array}$ & $\begin{array}{l}1,2 \\
7\end{array}$ & \pm & $\begin{array}{l}0,1 \\
8\end{array}$ & & $\begin{array}{l}0,4 \\
0\end{array}$ & \pm & $\begin{array}{l}0,1 \\
0\end{array}$ & & $\begin{array}{l}24,2 \\
2\end{array}$ & \pm & $\begin{array}{l}20,1 \\
6\end{array}$ & \\
\hline
\end{tabular}

Where: $\mathrm{CG}$ - control group

EG - experimental group

* - Validity of the difference according to Student's t-criterion

** - Validity of the difference according to Fischer's F-criterion

There is a more positive dynamics of value-based attitudes during the training and application of survival tactics by the experimental group employees. Their activities are much less dependent on uncomfortable conditions. For the experimental group employees the motive of forming stable skills of functioning in special conditions and achieving increased efficiency in service and combat activities are of high importance. 
Significant differences that characterize the degree of significance of individual elements in the experimental (EG) and control group (CG) employees are manifested in connection with the need to participate in systematic classes on tactical and special training. This is clearly seen in Figure 1 in the indicator of professional competence. There were also indicators of significant differences in the structure that determines the organizational and value relations of employees of the groups under consideration.

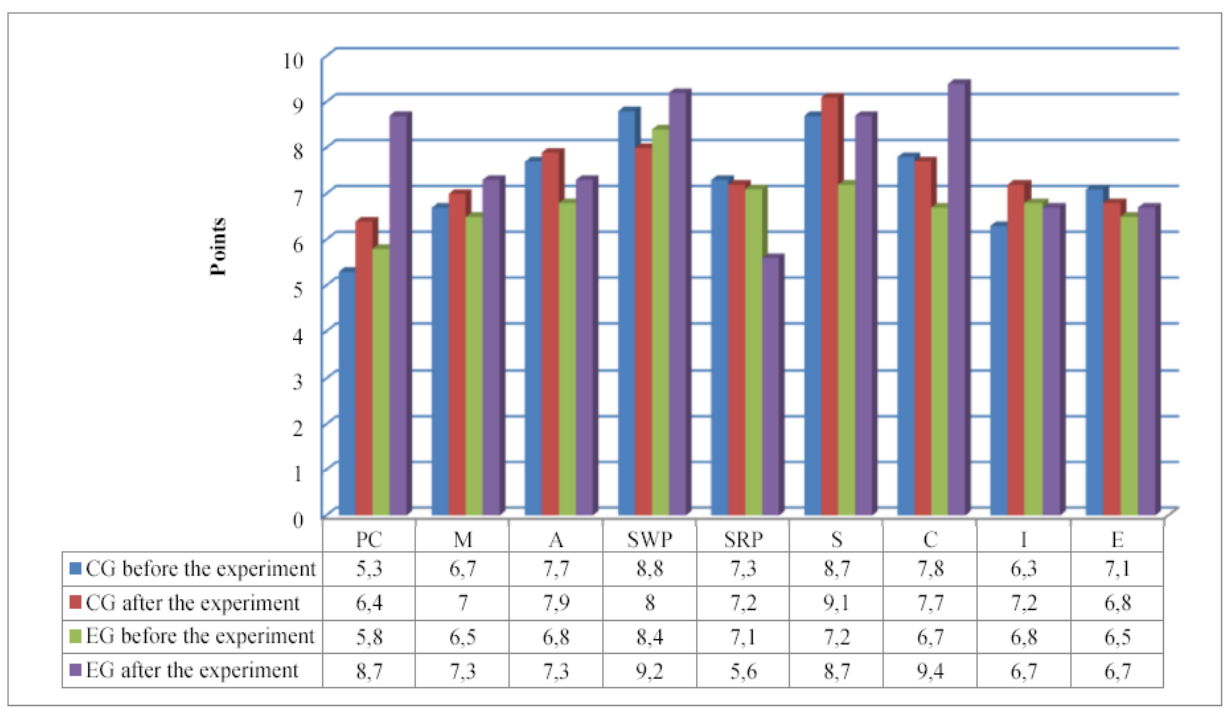

Fig. 1. Distribution of cadets' responses before and after the experiment with the use of "Career Anchors" method.

Where: $\mathrm{CG}$ - control group

$\mathrm{EG}$ - experimental group

PC - Professional competence

$\mathrm{M}$ - Management

E - Entrepreneurship

SRP - Stability of residency place

$\mathrm{S}$ - Service

$\mathrm{C}$ - Challenge

A - Autonomy (independence)

I - Integration of life styles

SWP - Stability of work place

The application of methods based on the stage-by-stage training and quality control of training improved the efficiency of training and, accordingly, the performance of actions of force enforcement officers in emergency situations. So when using impact munition in different situations, in the experimental group the number of errors decreased to zero, while in usual training groups the officers made various mistakes, both in the technique and tactics of using the munition. The experimental training groups showed the best results in counteracting the crowd and individuals participating in illegal actions. The experimental group showed a much higher level of knowledge and survival skills in extreme conditions. This is explained by the psychological qualities formed during the implementation of the experimental method. Besides, while applying the stage-by-stage method of training the trainees showed higher level of knowledge and skills when acting independently, as well as when interacting in group actions. 
Police officers' training to be prepared for taking actions in special conditions is not only the issue for local Agencies of Internal Affairs, but also for educational organizations of the Ministry of Internal Affairs of Russia. Higher education institutions of the Ministry of Internal Affairs of Russia should solve this problem through the educational process and effectively organized, regularly conducted service and combat training.

Improving the professional training of the personnel of the Agencies of Internal Affairs to be prepared for taking actions in emergences including theoretical, organizational and methodological aspects, is a part of the unified personnel policy of the Ministry of Internal Affairs of Russia and is an urgent issue of modern scientific and practical activities.

The standard system of specialists' training implies incoming control of knowledge and skills and control of skills in the end, i.e. at the end of training. This condition does not allow the assessment of knowledge and skills during the learning process. They are evaluated at the end of the entire course of training. This condition gives only a general idea of the specialist's level of training, it does not allow identifying the undigested material, unformed skills; this leads to ineffective actions that lead to the employee's injuries or death, as well as failure of the operation. In the method of training suggested by the authors the entire process is divided into certain stages with the tasks specific to the stage, the content and control of the capture of the studied material. This condition will allow for timely identifying the problems in grasping the educational material and focusing on problematic issues to resolve them.

The activity of the employees of the Ministry of Internal Affairs in order to perform operational service tasks is often associated with the need to act in non-standard situations with increased danger. When dealing with the consequences of emergencies and participating in special events, police officers face negative factors of life and healththreatening conditions that require prompt execution of the assigned tasks in a stressful state. This requires extreme mobilization of all internal human physiological reserves.

Behavioral responses in extreme situations are characterized by the level of physical, fire, tactical and special training, but this is the subjective perception of the situation, which affects the mental condition, that plays the leading role. Accordingly, preparing for the case of imergency helps to reduce the number of errors and increases the personnel's confidence in their actions.

The tasks that are performed by the employees of the Ministry of Internal Affairs are really specific, which makes it necessary: to study tactical training in emergency circumstances, to simulate operational service activity; here it is required to introduce element-by-element training in these situations that help to develop resilience and ability to respond adequately to a new situation.

Training of employees of the Ministry of Internal Affairs of Russia to act in extreme situations should be improved in accordance with the current dynamics of changes. The training method involves step-by-step implementation of complex tasks aimed at performing the techniques related to the elements of novelty, risk, danger, time limitation, long-term physical and mental stress. It is required to monitor the progress of their implementation, identify and eliminate errors of various types.

As a result of the study it was revealed that the developed system of stage-by-stage training based on increasing complexity of actions in special conditions, which takes into account the police officers' adaptation of to extreme conditions of operational service activity, is more efficient in relation to professional training, formation of collective interactions and relationships. In total, this contributed to the improvement of collective skills and increase of the level of service and combat interaction while solving the set training tasks.

Readiness for actions in special conditions of employees of the Ministry of Internal Affairs and its level should be evaluated by a set of criteria: the effectiveness of 
professional techniques and actions; the dynamics of indirect performance indicators; factor informativeness; keeping record of real achievements. For a number of categories, it is preferable to use a composite criterion based on the total indicator of tactical and special, physical and fire readiness, which includes the main control exercises, techniques, actions and the optimal set of tests.

To improve the effectiveness of employees' training in the Ministry of Internal Affairs to act in extreme situations a number of recommendations are suggested:

1. Implement a multi-component, stage-by-stage system for training officers to act in extreme situations in educational organizations and practical divisions of the Ministry of Internal Affairs of Russia during tactical and special training.

2. Training should be conducted taking into account the principle of training "from simple to complicated", that is with the gradually added complexity of tasks for the law enforcement officers' actions in emergency situations of various types.

3. Training should be conducted taking into account the principle of training on the principle of "from simple to complex", that is, with a gradual complication of tasks for the actions of employees of internal Affairs agencies in extreme situations of various types.

4. It is necessary to conduct stage-by-stage control over the digestion of the material and formation of skills to take actions in various conditions.

5. Along with the formation of the necessary amount of knowledge and skills it is necessary to develop psychological qualities (insistence, determination, ability to overcome fear, psychological stability).

6. It is necessary to develop the ability to navigate in space quickly, since this condition plays a key role in a number of operations.

7. You also need to pay more attention to teaching how to interact.

\section{Conclusions}

The study provides an in-depth and holistic view of the system for improving the law enforcement officers' training to be prepared to act in emergencies. The obtained data can be used to improve the efficiency of law enforcement officers' training for them to be ready to perform operational service tasks in emergencies.

\section{References}

1. $\quad$ N.E. Vodopyanova, Psychodiagnostics of stress, p. 227 (St.-Petersburg: Peter, 2009)

2. Y.L. Pomerantsev, Personal security of Department of Internal Affairs officers: the nature of the problem and ways of solving it, Bulletin of Vladimir Law Institute, 4, 131-133 (2009)

3. E.P. Ilyin, Psychophysiology of human states, p. 412 (St. Petersburg: Peter, 2005)

4. L.G. Pochebut, V.A. Chiker Organizational social psychology, p. 298 (Saint Petersburg: Publishing house «Rech», 2002).

5. D. Kalk, SWAT teams need strong leadership, Journal of Police, USA, 4, 38-39 (1998)

6. S. Katz, Officer down recovery training, Journal of Law and Order, USA, 3, 64-68 (1998)

7. S.N. Barkalov, I.V. Gerasimov, Physical preparation of cadets of educational institutions of the MIA of Russia: state, problems and ways of improvement, Society and law: scientific and practical journal, 4 (50), 299-304 (2014)

8. A.A. Karelin, Psychological tests, 273-276 (Moscow, 2005) 
9. V.I. Stepanyuk, Aspects of personal security of Department of Internal Affairs officers Journal of Science and practice, 2 (63), 174-176 (2015)

10. N.A. Alekseev, N.B. Kutergin, P.N. Voynov, A.N. Vorotnik, Some aspects of the training of police officers to arrest a criminal in confined spaces, Problems of law enforcement: international scientific and theoretical journal, 2, 33-37 (Belgorod, Belgorod Law Institute of the Ministry of Internal Affairs of Russia named after I.D. Putilin, 2014)

11. V.A Zolotenko, Improvement of professionally applied physical training of cadets in educational institutions MIA of Russia, dis. ... cand. of ped. Sciences, p.57 (Saint Petersburg: Saint Petersburg University of the Ministry of internal Affairs of Russian Federation, 2011)

12. V.A. Tarasov, L.I. Timoshenko, On the need for joint practical classes on special tactical, fire and special physical training. - Collection of materials of the VI interuniversity scientific and practical conference, p. 238 (Stavropol, 2013)

13. J. Niehaus, Realistic use-of-force training, Journal of Law and Order, USA, 6, 103106 (1997)

14. A.A. Trebenok, Innovative way of special combat training of cadets of educational institutions of the MIA of Russia, Vestnik of the Moscow University of the MIA of Russia, 8, 37-42(2010)

15. P.N. Voynov, A.A. Poydunov, B.A. Klimenko, P.A. Kadutskii, An integrated approach in the training of law enforcement officers to take action on detention of the armed and unarmed criminals, Problems of law enforcement: international scientific and theoretical journal, 2, 95-98 (Belgorod, Belgorod Law Institute of the Ministry of Internal Affairs of Russia named after I.D. Putilin, 2016)

16. D.D. Donskoy, S.V. Dmitriev, Psychosemantic motor actions control mechanisms in man, Journal of Theory and practice of physical culture, 9, 39-40 (1999)

17. V.D. Kryazhev, Human athletic abilities: definition, basic concepts and measurement problems Journal of Sports science bulletin, 4, 3-5 (2003)

18. S.V. Kuznetsov, N.L. Ponomarev, Tactics of actions of employees of internal Affairs bodies of the Russian Federtion the typical situations of service: educational-practical guide, p. 96 (Monography N. Novgorod: Nizhny Novgorod Academy of the Ministry of internal Affairs of Russia, 2013)

19. S. Stanard, Physical ability testing (The "Denver/Stanard" model) Journal of Law and Order, USA, 8, 22 (1994)

20. A.A. Tarasenko, P.N.Voynov, A.A. Nevmovenko, Peculiarities of police officers training to en-sure personal safety in service activities, Bulletin of Belgorod Law Institute of MIA of Russia, 1, 56-58 (Belgorod, Belgorod Law Institute of the Ministry of Internal Affairs of Russia named after I. D. Putilin, 2016)

21. D. BriUenham. and Stronger. Abs and Back - Human Kinetiks, p.248 (Leeds (UK), 1997)

22. J. Hanna, New aspects of knife training, Journal of Law and Order, USA, 12, 24 - 26 (1997)

23. C. Hennen, Staying prepared:nine fundamental principles for on-going police training, Journal of Law and Order, USA, 9, 85 - 87 (1996) 